\title{
MANAJEMEN RANTAI PASOK MANGGA MANALAGI DI KABUPATEN SITUBONDO DENGAN PENDEKATAN FOOD SUPPLY CHAIN NETWORKING
}

\author{
Puryantoro1), Evita Soliha Hani' ${ }^{2}$, Sri Subekti ${ }^{3)}$ \\ 1)Fakultas Pertanian Universitas Abdurachman Saleh, Situbondo 68362, \\ Indonesia,ryan_ss97fm@yahoo.co.id \\ 2)Fakultas Pertanian Universitas Jember, Jember,Indonesia, ita_hani@yahoo.com \\ 3)Fakultas Pertanian Universitas Jember, Jember,Indonesia, \\ srisubekti.unej@gmail.com
}

\begin{abstract}
ABSTRAK
Tujuan penelitian ini untuk mengetahui manajemen rantai pasok mangga manalagi di Situbondo.Penentuan daerah penelitian ditentukan dengan sengaja (Purposive Method) di Kecamatan Kapongan Kabupaten Situbondo. Pengambilan petani sampel dilakukan dengan menggunakan metode Proportional random sampling. Pengambilan responden pelaku rantai pasok mangga setelah petani ditentukan dengan metode Snowball sampling. Penelitian dengan pendekatan metode kualitatif dan kuantitatif. Data kualitatif dilakukan secara deskriptif sesuai dengan kerangka Food Supply Chain Networking (FSCN). Kondisi manajemen rantai pasok mangga manalagi di Kabupaten Situbondo saat ini masih belum berjalan dengan baik. Hal tersebut dapat terlihat pada struktur rantai pasok belum yang terintegrasi dengan baik antara anggota primer dalam rantai pasok. Hal tersebut dikarenakan aliran informasi hanya terjadi pada konsumen akhir, pedagang pengecer, pedagang pengepul dan pedagang pengumpul. Sementara petani tidak mendapatkan aliran informasi baik mengenai pasar, harga, kualitas dan kuantitas yang diinginkan konsumen kecuali petani yang tergabung dalam kelompok tani.
\end{abstract}

Kata Kunci : Supply Chain, FSCN, Mangga

\section{PENDAHULUAN}

Jawa Timur sebagai sentra produksi mangga mampu memenuhi 45,46 persen dari produksi nasional. Hal ini disebabkan hampir sebagian besar wilayah Jawa Timur mempunyai kondisi agro ekologi yang sesuai bagi pertumbuhan dan produksi tanaman mangga. Begitu pula dengan luas panen mangga di Jawa Timur setiap tahunnya mengalami peningkatan 5,1 persen. 
Di Situbondo sendiri buah mangga merupakan komoditas unggulan, dari beberapa jenis buah mangga yang ada, mangga manalagi merupakan ciri khas Kabupaten Situbondo sebagai kota mangga serta merupakan salah satu sentra produksi buah mangga di Indonesia.

Sebagai salah satu komoditas unggulan di Jawa Timur, hampir di setiap wilayah banyak dijumpai tanaman mangga, baik yang diusahakan secara kormersial atau memenuhi kebutuhan konsumen maupun yang diusahakan secara sub sistem atau hanya memenuhi kebutuhan keluarga, selain itu terbukti bahwa kornoditas mangga merupakan kornoditas buah-buahan yang banyak diminati konsumen, baik dari kalangan menengah kebawah maupun kalangan atas. Kualitas mangga yang dihasilkan juga akan berpengaruh terhadap permintaan konsumen akan produk tersebut.

Umumnya usahatani mangga belum dikelola secara intensif, akan tetapi lebih bersifat sebagai usaha sampingan. Sehingga sering dijumpai di masyarakat, tanaman mangga tumbuh secara alamiah dan tanpa perawatan di pekarangan atau tegal. Hal ini disebabkan oleh sifat tanaman mangga yang dapat tumbuh di dataran rendah maupun tinggi.

Menurut hasil Sensus Pertanian oleh Badan Pusat Statistik Kabupaten Situbondo (2014), dari 50 jenis tanaman hortikultura tahunan utama, mangga merupakan jenis tanaman hortikultura tahunan yang paling banyak diusahakan oleh rumah tangga usaha hortikultura (32,50 ribu rumah tangga) dengan rata-rata jumlah pohon yang diusahakan sebanyak 14 pohon per rumah tangga. Dengan jumlah pohon yang diusahakan sebanyak 482.276 pohon dan yang sudah berproduksi 304.836 pohon. (BPS, 2014).

Produksi mangga di Situbondo mengalami peningkatan setiap tahunnya. Setiap tahunnya produksi mangga Situbondo mengalami peningkatan. Tahun 2012 mengalami peningkatan sebesar 14,8 persen dari tahun 2011 (212.784 kw). Pada tahun $2013(402.247 \mathrm{kw})$ mengalami peningkatan sebesar 16,7 persen dari tahun $2012(286.790 \mathrm{kw})$.

Produksi mangga di Situbondo sebagian besar dilakukan dengan metode pengolahan yang sederhana atau konvensional, bahkan masyarakat cenderung membiarkan tanaman mangga tanpa adanya perawatan. Hal tersebut seringkali menyebabkan mangga yang dihasilkan tidak memenuhi persyaratan mutu yang telah ditetapkan konsumen.Persepsi petani mangga yang belum berorientasi mutu menyebabkan sebagian besar pelaku usaha tidak menerapkan Good Agricultural Process (GAP) dan Good Manufacturing Process (GMP). Hal tersebut mengakibatkan mutu mangga yang dihasilkan menjadi rendah sehingga menurunkan daya saing mangga Situbondo.

Selain masalah daya saing, sistem rantai pasok mangga yang terlalu panjang dan pemerataan pendapatan dalam rantai pasok mangga yang masih rendah merupakan masalah yang harus segera dibenahi. 
Hasil penelitian Supriatna (2010) menyebutkan bahwa pedagang besar mangga memperoleh keuntungan lebih tinggi dibandingkan pedagang agen, yaitu masing-masing Rp. 3.350 dan Rp. 1.460 per kg. Hal ini dikarenakan pedagang besar lebih banyak melakukan penanganan hasil dan juga lebih besar menanggung risiko rugi pada waktu harga jual mangga rendah. Sebaliknya pedagang agen mempunyai resiko rugi sangat kecil karena mereka dibayar melalui sistem komisi sepuluh persen dari total nilai penjualan.

Pedagang merupakan pihak yang memperoleh keuntungan paling tinggi dalam jaringan rantai pasok mangga dibandingkan para petani yang belum mencapai kesejahteraan yang seharusnya. Menurut Nugraha (2011) Salah satu cara untuk meningkatkan daya saing mangga dan kesejahteraan petani yaitu dengan menerapkan strategi manajemen rantai pasok yang berkesinambungan dan mampu mengefisiensikan sistem rantai pasok mangga sehingga pemerataan pendapatan diantara anggota jaringan rantai pasoknya dapat tercapai.

Tujuan dari penelitian ini adalah untuk mengatahui manajemen rantai pasok Mangga Manalagi di Situbondo yang meliputi aliran produk, aliran informasi dan aliran finansial.

\section{METODOLOGI}

Penentuan daerah penelitian ditentukan dengan sengaja (Purposive Method). Purposive Method merupakan pemilihan lokasi penelitian yang telah ditentukan terlebih dahulu.Data yang dikumpulkan dalam penelitian ini meliputi data primer dan data sekunder.

Pengambilan petani sampel dilakukan dengan menggunakan metode Proportional random sampling artinya pengambilan sampel dari keseluruhan populasi, sesuai dengan proporsi masing-masing sub populasi, yaitu Desa Curah Cottok, Desa Peleyan, dan Desa Kandang dengan mempertimbangkan jumlah petani responden yang memenuhi syarat sebagai petani sampel. Desa Peleyan diambil respondennya sebanyak 11 responden, Desa Curah Cottok sebanyak 11 responden, sedangkan Desa Kandang pengambilan sampelnya sebanyak 8 responden.

Pengambilan responden pelaku rantai pasok mangga setelah petani ditentukan dengan metode Snowball sampling yaitu dengan cara menelusuri saluran rantai pasok buah mangga manalagi yang ada di Kecamatan Kapongan Kabupaten Situbondo berdasarkan informasi dari petani sampai pada anggota rantai pasok berikutnya.

Penelitian ini membutuhkan pendekatan metode kualitatif dan kuantitatif untuk mengolah data primer dan sekunder.Untuk menganalisis rantai pasok diperlukan data kualitatif dan kuantitatif. Data kualitatif dilakukan secara 
deskriptif sesuai dengan kerangka Food Supply Chain Networking (FSCN) dari Lambert dan Cooper (2000) yang dimodifikasi oleh Vorst (2006).

\section{HASIL DAN PEMBAHASAN}

Jumlah petani responden yaitu 30 orang yang semuanya masih berusia produktif.Seperti pada Tabel 1, pada responden usia produktif, 2 (dua) orang atau 6,7 persen berada pada kisaran umur 35-39 tahun, 6 (enam) orang atau 20 persen berumur antara 40-44 tahun, 7 (tujuh) orang atau 23,3 persen berumur 45-49 tahun, 5 (lima) orang atau 16,7 persen berumur 40-54 tahun, dan 6 (enam) orang atau 20 persen berumur 55-69 tahun, sedangkan kisaran umur 60-64 tahun lebih banyak yaitu 4 (empat) orang.

Usia petani responden termasuk dalam kelompok usia yang produktif. Dimana usia ini berpengaruh terhadap produktivitas kerja petani. Dengan banyaknya petani dalam kelompok umur produktif di suatu daerah memungkinkan daerah tersebut dapat berkembang.Hal ini disebabkan petani pada umumnya lebih mudah menerima informasi dan inovasi baru serta lebih cepat mengambil keputusan dalam penerapan teknologi baru yang berhubungan dengan usahataninya. Dengan kondisi usia tersebut juga diharapkan petani mampu membaca pasar dan memanfaatkan peluang untuk meningkatkan penerimaan usahataninya.

\section{Identitas Responden Anggota Rantai Pasok Setelah Petani}

Pedagang atau lembaga pemasaran yang terlibat pemasaran buah mangga manalagi di Kecamatan Kapongan Kabupaten Situbondo adalah pedagang pengumpul, pedagang pengepul, dan pedagang pengecer. Dari petani buah mangga manalagi menjual ke pedagang atau lembaga pemasaran. Layaknya suatu pengalaman dan pola pikir yang cermat yang dalam hal ini pengalaman, umur, dan pendidikan sangat mempengaruhi keberhasilan dalam berdagang. Berdasarkan hasil penelitian rantai pasok buah mangga manalagi di Kecamatan Kapongan Kabupaten Situbondo, lembaga pemasaran yang terlibat dalam proses penyampaian buah mangga manalagi dari petani sampai ke konsumen terdapat beberapa lembaga pemasaran. Berikut ini identitas responden lembaga perantara pemasaran buah Mangga di Kecamatan Kapongan, Kabupaten Situbondo.

\section{a) Pedagang Pengumpul}

Pedagang pengumpul pada umumnya mendapatkan buah mangga manalgi langsung dari petani dengan cara sistem tebasan dan ijon. Umur responden pedagang pengumpul buah mangga manalagi tergolong dalam usiaproduktif antara 32-56 tahun. Pada umur kisaran 32-36 tahun sebanyak 5 (lima) orang atau 25 persen, usia 41-44 tahun sebanyak 1 orang atau 5 persen. Sedangkan untuk kisaran umur 45-48 tahun dan 49-52 tahun yang masing-masing 
sebanyak 4 (empat) orang atau 20 persen dan 6 orang atau 30 persen pedagang pengumpul pada kisaran usia 53-56 tahun. Pada usia ini pedagang pengumpul masih mampu bekerja dengan baik, sehingga pedagang yang usianya masih produktif.

Tingkat pendidikan responden pedagang pemgumpul dalam pemasaran buah mangga manalagi adalah tidak tamat SD 3 orang atau 15 persen, tamatan SD sebanyak 7 orang atau 35 persen, tamatan SMP sebanyak 5 orang atau 25 persen dan tamat SMA sebanyak 5 orang atau 25 persen. Tingkat pendidikan pada pedagang penebas yang mayoritas tamatan SD mempengaruhi strategi penjualan ke Pedagang pengepul sehingga dalam menjalankan kegiatan penjualan buah mangga manalagi pedagang pengumpul tidak melakukan Gradingbuah mangga manalagi. Hal ini disebabkan karena kurangnya pengalaman dan tidak mau mengelurakan biaya sortir serta waktu.

Lama berusaha akan mempengaruhi pengalaman mereka dalam memasarkan buah mangga Arumanis. Lama usaha pada pedagang penebas sekitar 3-31 tahun. Semakin lama pengalaman berdagang semakin mudah bagi mereka untuk mendapatkan produksi buah mangga manalagi hal ini disebabkan karena mereka sudah dikenal oleh produsen atau petani.

\section{b) Pedagang Pengepul}

Pedagang Pengepul mendapatkan buah mangga manalagi dari kiriman Pedagang Pengumpul, petani dan kelompok tani dengan volume pembeliannya besar berkisar 8 sampai 12 ton setiap sekali transaksi. Tabel 1 menunjukkan identitas responden Pedagang Pengepul buah mangga manalagi di Kecamatan Kapongan Kabupaten Situbondo.

Berdasarkan Tabel 1 dapat diketahui bahwa umur Pedagang Pengumpul buah mangga manalagi tergolong dalam usia produktif antara 32-56 tahun. Tingkat pendidikan pedagang pegepul adalah tamat SMA sebanyak 4 (empat) orang atau 40 persen dan tamat SMP sebanyak 5 (lima) orang (50 persen). Serta 1 orang atau 10 persen pedagang pengumpul tidak tamat SD. Keseluruhan responden lembaga pemasaran sudah mengikuti pendidikan formal dengan tingkat pendidikan yang berbeda. Lama usaha berdagang pada responden Pedagang Pengepul buah mangga manalagi yaitu berkisar antara 25-31 tahun sebanyak 1 (satu) orang atau 10 persen dan 18-24 tahun, 4-10 tahun dan $\leq 3$ masingmasing sebanyak 2 (dua) orang atau 20 persen. 3 orang atau 30 persen mempunyai pengalaman selama kisaran 11-17 tahun. Hal inilah yang mempengaruhi strategi pemasaran buah mangga manalagi, dimana Pedagang pengepul mampu membaca kondisi pasar dan persaingan harga. 
Tabel 1. Jumlah dan Persentase Petani Responden Berdasarkan Usia, Pendidikan, Pengalaman Usaha Tani, Jumlah Pohon dan Sistem Penjualan

\begin{tabular}{|c|c|c|c|c|c|}
\hline Responden & Usia & Pendidikan & $\begin{array}{c}\text { Pengalaman Usaha } \\
\text { Tani (tahun) }\end{array}$ & $\begin{array}{l}\text { Jumlah } \\
\text { Pohon }\end{array}$ & $\begin{array}{c}\text { Sistem } \\
\text { Penjualan }\end{array}$ \\
\hline 1 & 36 & SMA & 5 & 3 & Ijon \\
\hline 2 & 39 & SMA & 5 & 3 & Ijon \\
\hline 3 & 41 & $\mathrm{SD}$ & 5 & 3 & Ijon \\
\hline 4 & 44 & Diploma & 6 & 3 & Ijon \\
\hline 5 & 44 & SD & 5 & 4 & Ijon \\
\hline 6 & 42 & Diploma & 7 & 10 & Sewa \\
\hline 7 & 40 & $\mathrm{SD}$ & 8 & 3 & Ijon \\
\hline 8 & 43 & SMA & 5 & 12 & Sewa \\
\hline 9 & 45 & SMP & 6 & 3 & Ijon \\
\hline 10 & 47 & SD & 6 & 5 & Ijon \\
\hline 11 & 48 & $\mathrm{SD}$ & 7 & 3 & Ijon \\
\hline 12 & 48 & SMP & 10 & 5 & Tebasan \\
\hline 13 & 46 & SD & 9 & 12 & Tebasan \\
\hline 14 & 49 & SMP & 6 & 14 & Tebasan \\
\hline 15 & 48 & SD & 7 & 5 & Ijon \\
\hline 16 & 53 & SMP & 6 & 5 & Ijon \\
\hline 17 & 50 & SD & 5 & 3 & Ijon \\
\hline 18 & 53 & SMP & 14 & 14 & Tebasan \\
\hline 19 & 52 & SD & 11 & 3 & Ijon \\
\hline 20 & 54 & $\mathrm{SD}$ & 13 & 4 & Ijon \\
\hline 21 & 55 & SD & 11 & 13 & Tebasan \\
\hline 22 & 56 & $\mathrm{SD}$ & 10 & 3 & Ijon \\
\hline 23 & 55 & $\mathrm{SD}$ & 12 & 3 & Ijon \\
\hline 24 & 59 & SMP & 10 & 14 & Tebasan \\
\hline 25 & 57 & SD & 13 & 4 & Tebasan \\
\hline 26 & 58 & SD & 10 & 4 & Ijon \\
\hline 27 & 60 & SMP & 18 & 4 & Ijon \\
\hline 28 & 64 & $\mathrm{SD}$ & 14 & 3 & Tebasan \\
\hline 29 & 62 & $\mathrm{SD}$ & 12 & 3 & Ijon \\
\hline 30 & 63 & SD & 12 & 3 & Ijon \\
\hline
\end{tabular}

Sumber : Data Primer (2016), diolah

\section{c) Pedagang Pengecer Lokal}

Pedagang Pengecer mendapatkan buah mangga manalagi dari petani dengan sistem ijon untuk selanjutnya dipasarkan melalui kios yang dimiliki.Hasil penelitian terdapat 1 (satu) orang pedagang pengecer di Kecamatan Kapongan. Berikut ini identitas responden Pedagang Pengecer buah mangga manalagi di Kecamatan Kapongan Kabupaten Situbondo : 


$\begin{array}{ll}\text { Nama } & : \text { Sunjoto } \\ \text { Usia } & : 50 \text { tahun } \\ \text { Pendidikan } & : \text { SMA } \\ \text { Pengalaman Usaha } & : 7 \text { tahun }\end{array}$

\section{d) Pasar Induk atau Pedagang Pengecer Luar Kota}

Pasar induk mendapatkan buah mangga manalagi dari pedagang pengepul di daerah. Pasar Induk yang menjadi tujuan pemasaran mangga manalagi Situbondo adalah pasar induk di Surabaya, Malang, Yogjakarta dan Jakarta. Peneliti tidak mewawancarai aktor/pelaku di pasar induksehingga juga tidak mewawancarai pelaku pada rantai pasok berikutnya yaitu pedagang pengecer luar kota, peneliti memperoleh data mengenai pasar induk dan pedagang pengecer luar kota dari pedagang pengepul.

\section{Manajemen Rantai Pasok Mangga Manalagi di Situbondo}

Pembahasan mengenai manajemen rantai pasok mangga manalagi pada penelitian ini akan menggunakan suatu kerangka kerja (framework) analisis rantai pasokan yang dikembangkan oleh Lambert dan Cooper dalam Vorst (2005) yang kemudian dimodifikasi oleh Vorst (2005) Food Supply Chain Networking (FSCN). Pembahasan mengenai manajemen rantai pasok pada agribisnis mangga manalagi dengan menggunakan kerangka kerja FSCN akan menganalisis beberapa aspek yakni :

\section{Struktur Rantai Pasok}

Aliran rantai pasok mangga di Kabupaten Situbondo dipengaruhi oleh perbedaan cara penjualan produksi mangga oleh petani. Petani melakukan penjualan melalui pedagang pengumpul dan pedagang pengepul. Secara umum, hasil penelitian aliran komoditas mangga ada tiga model rantai pasok. Model pertama untuk rantai pasok mangga dengan penjualan melalui pedagang pengumpul sebanyak 23 petani mangga. Pada model rantai pertama ini petani menjual hasil produksi mangganya melalui pedagang pengumpul. Berdasarkan hasil wawancara terdapat 20 pedagang pengumpul diperoleh model seperti pada Gambar 1.

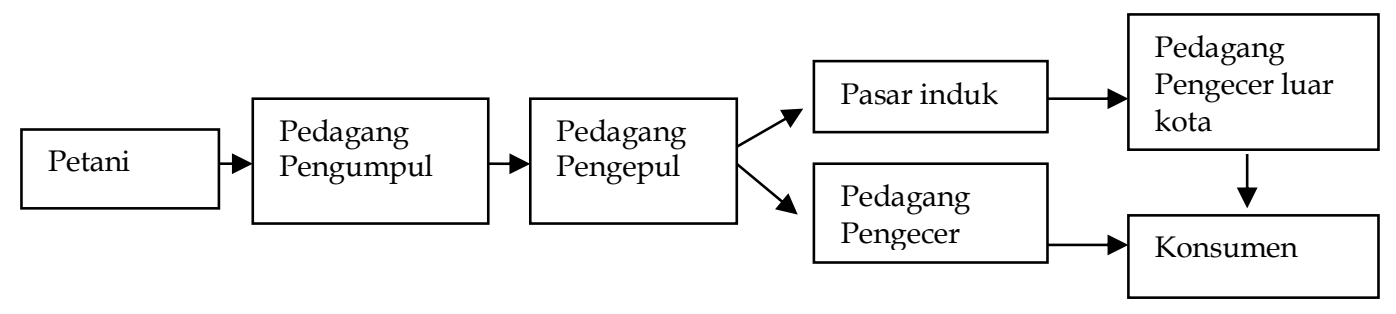

Gambar 1. Model Rantai Pasok melalui Pedagang Pengumpul

Sumber : Data Primer (2016), diolah 
Hasil penelitian untuk model kedua rantai pasok tanpa melalui rantai pengumpul sebanyak 5 petani dari 30 responden petani mangga seperti pada Gambar 2.

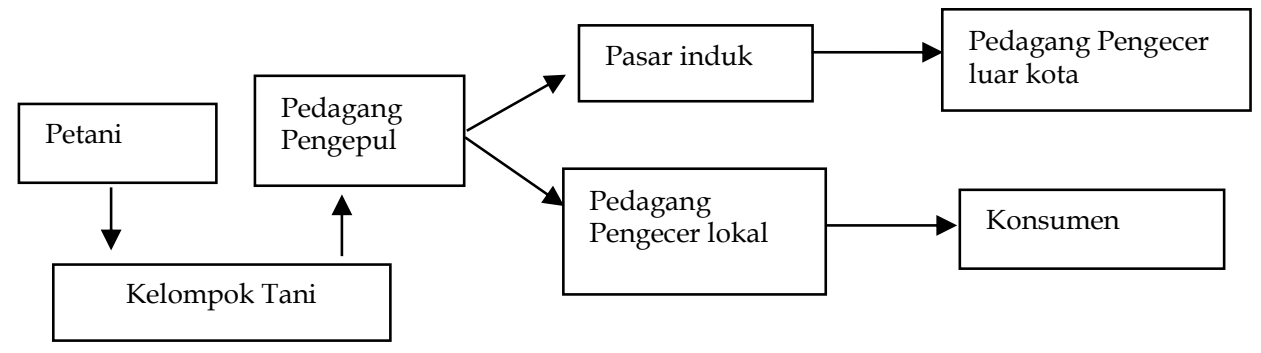

Gambar 2. Model Rantai Pasok melalui Kelompok Tani

Sumber : Data Primer (2016), diolah

Hasil penelitian untuk model ketiga rantai pasok tanpa melalui rantai pengumpul dan pengepul sebanyak 2 petani dari 30 responden petani mangga seperti pada Gambar 3.

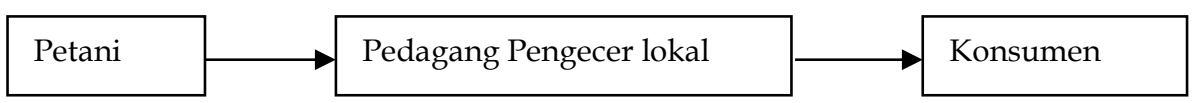

\section{Gambar 3. Model Rantai Pasok langsung pada pedagang pengecer}

Sumber : Data Primer (2016), diolah

Gambar 4 menunjukkan pola aliran dalam rantai pasok mangga di Kabupaten Situbondo berdasarkan hasil penelitian terhadap petani mangga, pedagang pengumpul, pedagang pengepul dan pedagang pengecer mangga.

Aliran komoditas mangga terdiri dari 3 pola :

Pola 1 : dimulai dari petani mangga dikumpulkan oleh pedagang pengumpul. Pengumpul menghantarkan mangga kepada pedagang pengepul menggunakan moda transportasi pick up, sepeda motor dan sepeda pedal. Sesampainya di pedagang pengepul mangga kembali didistribusikan melalui pedagang pengecer dalam kota dan pasar induk luar kota yang dikemas dalam kotak peti dengan menggunakan truck pengangkut barang dan sampailah kepada konsumen akhir.

Pola 2 : Mangga mengalir dari petani langsung ke pedagang pengepul melalui kelompok tani untuk berikutnya dikelola hingga ke konsumen. 


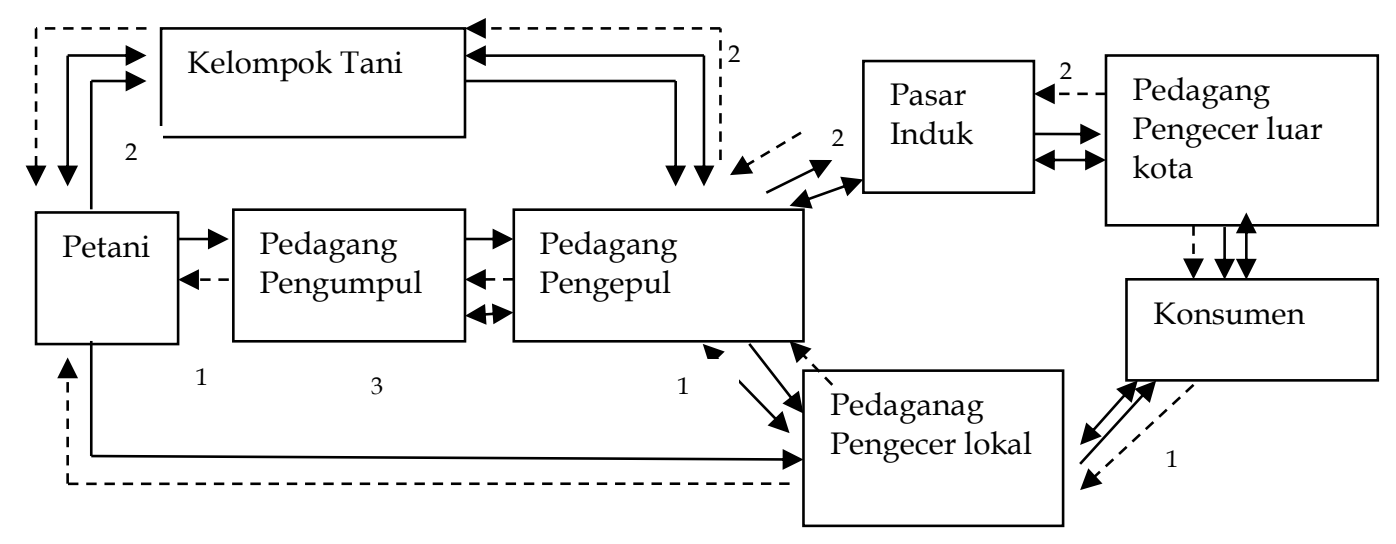

Gambar 4. Pola Aliran dalam Rantai Pasok Mangga di Kabupaten Situbondo Sumber : Data Primer (2016), diolah

\section{Keterangan :}

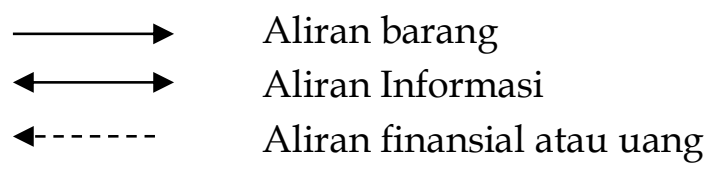

Pola 3 : Pedagang pengecer lokal memiliki pola sendiri dalam mendistribusikan produk mangga hingga sampai ke konsumen, pola ini lebih singkat yakni pedagang pengecer melakukan sistem sewa dengan petani langsung dan produknya langsung dijual ke konsumen di kios yang dimiliki pedagang pengecer.

Aliran finansial mengalir dari konsumen, pedagang pengecer lokal, serta pedagang pengecer luar kota di pasar induk, pedagang pengepul, pedagang pengumpul dan petani. Untuk petani yang menjual langsung pada pedagang pengepul, aliran finansial lebih pendek yaitu konsumen, pedagang pengecer, pedagang luar kota dan petani. Aliran uang lebih pendek lagi adalah aliran dari retailer yang melakukan pembelian mangga langsung ke petani, uang mengalir dari konsumen ke pedagang pengecer lokal dan langsung ke petani.Pedagang pengecer di pasar induk dan pedagang pengepul membayar dengan sistem tunda paling lama 1 minggu.Pada petani, pedagang pengumpul membayar langsung sesuai dengan jumlah mangga yang diambil.

Sistem komunikasi belum terintegrasi dengan baik antara anggota primer dalam rantai pasok. Aliran informasi hanya terjadi pada konsumen akhir, pedagang pengecer, pedagang pengepul dan pedagang pengumpul.Sementara petani tidak mendapatkan infomasi baik mengenai harga, kualitas dan kuantitas yang diinginkan konsumen maupun mengenai pasar kecuali petani yang tergabung dalam kelompok tani dan atau pedagang pengecer yang membeli produk langsung dari petani. 


\section{Manajemen Jaringan dan Rantai}

Dari hasil penelitian rantai pasok mangga di Kabupaten Situbondo belum seluruhnya menggunakan sistem manajemen yang baik. Koordinasi antara pedagang pengumpul dengan petani tidak termanajemen dengan baik hal ini terlihat ketika pengumpul akan melakukan panen mangga tidak adanya perencanaan tanpa melihat peluang pasar di pengepul.

Menurut Qhoirunisa (2014) pemilihan mitra adalah proses memilih rekan kerja untuk dapat bekerja sama dalam suatu usaha. Kinerja mitra yang dipilih oleh anggota rantai pasok akan menentukan suatu usaha dan dalam rangka mencapai tujuan rantai pasok yaitu memenuhi kepuasan konsumen diperlukan pemilihan mitra sesuai kebutuhan anggota rantai pasok. Petani mangga di Situbondo memiliki kriteria didalam menentukan siapa yang dapat menjadi mitra didalam menjual hasil panennya. Kriteria atau alasan petani mangga didalam menentukan siapa pembeli mangga adalah yang pertama karena penawar dengan harga tinggi sebanyak 6 orang (30 persen), serta karena alasan langganan yang membeli mangganya sebanyak 9 orang (50 persen). Sementara pertimbangan petani mangga menjual mangga kepada langganan karena langganan tersebut selalu membayar dimuka dan petani sudah percaya kepada langganan tersebut. Langganan tersebut biasanya memiliki kedekatan lokasi dengan petani mangga Alasan petani berikutnya dalam memilih mitra atau pembeli mangganya adalah karena telah terikat pinjaman utamanya petani yang melakukan penjulan mangga dengan sistem ijon atau kontrak sebanyak 15 orang (20 persen).

Dari hasil penelitian diperoleh data bahwa tidak ada kontrak secara tertulis baik dari pihak pedagang pengepul kepada pengumpul dan petani. Kerjasama dilakukan dengan menggunakan prinsip kepercayaan dengan memegang komitmen, rasa saling ketergantungan, dan saling membutuhkan satu sama lain. Petani hanya akan menjual mangganya pada pengumpul yang siap membayar ketika petani membutuhkan uang (untuk sistem tebasan).

Pengumpul juga hanya akan menjual mangga pada pedagang pengepul yang memberikan harga tertinggidan atau yang telah memberikan bantuan sarana produksi mangga petani. Pada sistem penjualan secara tebasan atau ijon sistem kontraktual antara petani dan pengumpul hanya berupa kuitansi pembayaran.

Begitupun kontraktual antara pedagang pengepul dengan pedagang kios di pasar induk hanya berdasarkan kepercayaan atas kerjasama yang telah terjalin tanpa adanya kontrak tertulis.Kesepakatan lainnya yang tak tertulis adalah mengenai komisi penjualan mangga di pasar induk sebesar 10 persen untuk pedagang kioas dari harga jual mangga dipasar tidak tertera dalam kontrak.

Kesepakatan tertulis yang ditemui di lapangan hanya terdapat pada 1 pedagang pengecer yang memiliki kios di pinggir jalan pantura kecamatan Kapongan. Pedagang pengecer lokal ini melakukan kontrak tertulis dengan petani yang salah satu isi kontraknya fokus pada masa lama kontrak mangga. Pedagang 
pengecer ini mendistribusikan produk mangga hanya dengan pola dua arah petani ke retailer.

Dari 4 (empat) anggota rantai pasok mangga di Kecamatan Kapongan mulai dari petani, pedagang pengumpul, pedagang pengepul dan pedagang pengecer hanya 1 (satu) anggota rantai pasok yaitu pengecer yang sistem kontraktualnya dibuat secara tertulis. Hal ini mengartikan bahwa untuk sistem kontraktual sesama anggota ranti pasok mangga masih belum terdokumentasikan dengan baik.

Sistem pembayaran pada tingkat petani dilakukan secara langsung berapa banyak hasil panen dari kebun/pekarangan, hasil tersebut yang harus dibayar oleh pengumpul.Untuk sistem penjualan mangga secara ijon transaksinya dilakukan diawal kesepakatan kerjasama. Sedangkan sistem pembayaran di tingkat pengumpul dilakukan dengan berbagai cara, tergantung kesepakatan pengumpul dan pedagang pengepul. Kesepakatan tersebut berupa pengumpul dibayar langsung oleh pedagang pengepul pada saat mengirim mangga langsung ke lokasi pedagang ataupun dengan pembayaran tunda. Dari 20 pedagang pengumpul yang diwawancarai terdapat 16 pedagang pengumpul dengan sistem pembayaran tunda dan 4 pedagang pengumpul menerima pembayaran uang secara tunai dari pedagang pengepul. Penundaan pembayaran biasanya bisa sampai sekitar 1 minggu.

Begitu pula dengan transaksi antara pedagang pengepul dengan pedagang pengecer di pasar induk luar kota maupun pedagang pengecer lokal sistem pembayaran juga dilakukan dengan pembayaran tunda. Penundaan pembayaran biasanya bisa sampai sekitar 1 minggu atau sesuai dengan lakunya mangga di pasar induk.

\section{Sumber Daya Rantai}

Sumber daya fisik yang dimiliki petani mangga adalah lahan pekarangan atau lahan kering/tegal dengan luas yang beragam, antara 0,1 sampai dengan 1 hektar. Petani mangga juga memiliki peralatan yang digunakan dalam budidaya mangga, peralatan yang dimiliki adalah cangkul, parang dan arit.

Beberapa petani yang menjual langsung hasil panen ke pedagang pengepul melalui kelompok tani juga memiliki alat petik buahuntuk proses pemanenan. Sumberdaya fisik yang sangat berpengaruh adalah jalan, dan hingga saat ini banyak diantara petani yang memiliki lahan yang sulit diakses oleh kendaraan bermotor, hal ini menyebabkan ongkos angkut yang ditanggung oleh petani menjadi besar.

Sumber daya fisik yang dimiliki oleh pedagang pengumpul meliputi lahan, prasarana pendukung, dan kendaraan. Terdapat beberapa pedagang pengumpul yang juga melakukan kegiatan budidaya mangga. Sumber daya fisik peralatan budidaya sebagai prasarana pendukung yang dimiliki oleh pedagang pengumpul sama seperti peralatan yang dimiliki oleh petani mangga. Pedagang 
pengumpul lebih banyak memerlukan sumber daya fisik untuk melakukan aktifitas pemasaran mangga seperti keranjang dan tali rafia.Pedagang pengumpul menggunakan kendaraan berupa sewa mobil pick up, sepeda motor dan sepeda pedaluntuk melancarkan proses pembelian dan penjualan.

Sumberdaya fisik yang dimiliki oleh pedagang pengepul lebih banyak dibanding dengan pedagang pengumpul. Pedagang pengepul memiliki gudang, timbangan, kendaraan serta pegawai yang lebih banyak karena pedagang luar kota memiliki kegiatan sortasi, packing dan grading mangga. Pedagang pengepul juga memiliki alat semprot untuk pembasmian hama dan penyakit tanaman mangga untuk dipinjamkan kepada pedagang pengumpul mitra agar tanaman mangga petani yang terikat kontrak dengan pengumpul menghasilkan mangga yang berkualitas.

Aspek permodalan dalam rantai pasok mangga ini dapat dikatakan belum mapan. Pembiayaan khususnya ke anggota rantai pasok petani masih sulit karena dari segi kelayakan usahanya belum memenuhi syarat. Disamping dilihat dari aspek kelayakan usaha (kondisi fisik, sarana produksi, dan penjualan), evaluasi dan peninjauan juga dilakukan terhadap kelayakan aspek keuangan. Pihak bank dalam mengadakan evaluasi juga memastikan bagaimana pengelolaan kredit dan persyaratan lainnya dapat dikelola dengan baik oleh petani sehingga mampu menunjang keberhasilan proyek pembiayaan.

Tabel 2. Sumber Modal Anggota Rantai Pasok

\begin{tabular}{lccc}
\hline \multirow{2}{*}{ Anggota Rantai Pasok } & \begin{tabular}{c} 
Sodal \\
\cline { 2 - 4 }
\end{tabular} & $\begin{array}{c}\text { Pinjaman } \\
\text { Sendiri (\%) }\end{array}$ & $\begin{array}{c}\text { Pinjaman Pihak Anggota } \\
\text { Rantai Pasok (\%) }\end{array}$ \\
\hline Petani & 73 & 10 & 17 \\
Pedagang Pengumpul & 25 & 35 & 5 \\
Pedagang Pengepul & - & 100 & - \\
Pedagang Pengecer Lokal & - & 100 & - \\
\hline
\end{tabular}

Sumber : Data Primer (2016), diolah

Petani yang memiliki lebih dari 10 pohon mangga dan pedagang pengumpul jika tidak memiliki modal berupa pestisida dan permodalan untuk perawatan pohon mangga disediakan oleh pedagang pengepul dengan kesepakatan dan jaminan bahwa mangganya akan dijual pada pedagang pengepul tersebut.

\section{Proses Bisnis Rantai Pasok}

Hubungan kerjasama antara petani, pengumpul dan pedagang pengepul dan retailer merupakan satu hal yang akan dianalisis dalam penelitian ini. Ada hubungan yang harus dibina selain hubungan profesi untuk tetap menjaga hubungan baik, maka pedagang pengepul tidak segan-segan untuk memberikan 
bantuan kepada petani atau pengumpul ketika mereka sedang membutuhkan, misalnya untuk memenuhi kebutuhan rumah tangga petani atau pengumpul. Dari hasil wawancara diketahui bahwa pengumpul mengetahui dengan pasti karakteriktik petani yang sangat sensitif, sehingga memang untuk hubungan ini harus dilakukan perlakuan khusus, misalnya dengan memberikan uang untuk membayar uang sekolah anak ataupun untuk membeli beras keluarga tersebut.

Hubungan yang dijalin seperti ini cukup memuaskan kedua pihak, karena dipandang saling menguntungkan untuk kedua belah pihak. Hal ini juga yang menjadikan saling ketergantungan antara kedua belah pihak. Hubungan kesalingtergantungan ini adalah apa yang di motivasi keinginan nuntuk menegosiasikan transfer fungsional, berbagai informasi kunci, dan berpartisipasi dalam perencanaan opersional bersama.

Pola distribusi dalam rantai pasokan mangga menjabarkan tiga komponen utama, yakni aliran produk (mangga), aliran uang, dan aliran informasi. Proses penyampaian tiga komponen tersebut penting diketahui agar dapat dianalisis apakah aliran distribusi dalam rantai pasokan sudah berjalan lancar atau masih terkendala.

\section{Aliran Produk}

Aliran produk berawal dari petani dimana petani menanam mangga manalagi yang panen setahun sekali.Pada bulan Juni - Desember menjadi bulan musim mangga. Dari hasil penelitian diketahui bahwa 60 persen atau 18 orang dari 30 sampel petani mangga mengusahakan mangga pada lahan pekarangan yang mereka miliki, 7 petani (23 persen) mangga diusahakan pada lahan tegal dan tumpangsari dengan tanaman pangan dan 7 petani (17 persen) budidaya mangga pada lahan tegal secara monokultur. Proses pemanenan mangga biasanya hanya berlangsung 1 hari saja yang dilakukan oleh pedagang pengumpul jika petani menjual mangga dengan sistem tebasan ataupun ijon dan sewa. Petani di daerah penelitian melakukan penjualan mangga kepada pedagang pengumpul dengan sistem tebasan sebanyak 5 petani (16,7 persen) dan sistem ijon sebanyak 23 petani (76,7 persen) dan sistem sewa sebanyak 2 petani (6,6 persen). Dalam mengalirkan produk mangga manalagi petani tidak mengalami kesulitan untuk menjual produknya. Sebelum mangga mengalir ke pedagang pengepul ataupun pedagang pengumpul tidak satupun dari petani yang melakukan sortasi, grading maupun packing mangga. Hal tersebut dikarenakan petani hanya menganggap usaha tani mangga sebagai penghasilan sampingan yang tidak begitu banyak berpengaruh terhadap pendapatan terlebih bagi mereka yang melakukan penjualan dengan sistem ijon atau kontrak seluruh perawatan tanaman diserahkan kepada penyewa pohon mangga tersebut. Terkecuali 5 petani mangga yang tergabung dalam kelompok tani melati 2 di Desa Kapongan, Kecamatan Kapongan melakukan perawatan tanaman mangga sendiri karena telah bermitra dengan pedagang pengepul sehingga mendapatkan bantuan pinjaman modal pengobatan untuk perawatan tanaman. Setelah mangga siap panen, pedagang pengumpul yang 
menebas atau menyewa pohon mangga petani akan melakukan pemanenan. Dari pedagang pengumpul kemudian dibawa ke pedagang pengepul, sesampainya di pedagang pengepul iniah dilakukan kegiatan sortir, grading dan packing mangga.Sementara itu untuk 5 petani yang tergabung dalam kelompok tani mangga melati 2 di Desa Kapongan aliran produk langsung ke pedagang pengepul tanpa melalui pedagang pengumpul. Dari tangan pedagang pengepul dilanjutkan lagi distribusi mangga ke pasar induk di beberapa kota tujuan seperti Jakarta, Yogyakarta, Surabaya dan Malang melalui kios di pasar induk lalu terdistribusi melalui pengecer luar kota. Sementara pedagang pengecer lokal mendapatkan produk langsung dari petani mangga untuk kemudian didistribusikan ke konsumen di kios mangga.Secara otomatis peran pedagang pengecer lokal ini bertambah untuk melakukan sorting, grading dan packing.

Aliran produk mangga dari petani hingga pedagang pengepul belum terintegraisi dengan baik, belum ada siklus yang pasti sehingga baik waktu pengiriman ataupun kuota yang dikirim tidak bisa diprediksi dengan baik, begitupun aliran produk dari pedagang pengepul ke pasar induk juga tidak dapat diprediksi baik kuota, waktu pengiriman, dan harga yang diperoleh.

\section{Aliran Finansial}

Modal merupakan komponen penting dalam rantai pasokan mangga yang digunakan untuk kegiatan budidaya serta pembelian mangga dari petani.Modal usaha untuk kegiatan pemeliharaan seperti pembelian bibit, pupuk dan upah tenaga kerja selama ini petani menggunakan modal sendiri serta pinjaman dari pedagang pengepul maupun perbankan.

Aliran finansial berawal dari konsumen baik konsumen dari luar kota yang pembeliannya melalui pasar induk maupun konsumen dalam kota yang melakukan pembelian melalui pedagang pengecer lokal dimana konsumen mengalirkan uang melalui pembelian buah mangga yang sesuai dengan kriteria mereka. Konsumen melakukan pembayaran secara tunai kepada retailer. Pedagang pengecer di pasar induk mengalirkan uang ke pedagang pengepul dengan pembayaran tunda maksimal 1 minggu. Waktu penundaan pembayaran ini tergantung pada cepat tidaknya mangga laku di pasar, semakin cepat mangga laku maka pengiriman uang ke pedagang pengepul juga akan semakin cepat dengan sistem pembayaran melalui transfer perbankan. Sesampainya uang di pedagang pengepul, uang berikutnya mengalir ke pedagang pegumpul di tempat/kios mangga milik pengepul lalu mengalir ke petani melalui pedagang pengumpul atau kelompok tani. Petani yang tergabung dalam kelompok tani sendiri meminjam modal kepada pedagang pengepul tanpa jaminan apa- apa hanya bermodal kepercayaan dan faktor kedekatan,.Pinjaman sendiri dikatakan sebagai pinjaman pribadi bukan modal usaha. Biasanya pinjaman ini berupa benih, pupuk, dan uang. Pengelolaan aliran finansial rantai pasok mangga di Situbondo bisa dikatakan sudah dikelola dengan baik, kekurangannya hanya 
tidak adanya kesepakatan tertulis di semua anggota rantai pasok termasuk mengenai kesepakatan komisi 10 persen dari pedagang pengepul untuk setiap mangga yang laku terjual pada kios di pasar induk

\section{Aliran Informasi}

Aliran distribusi informasi merupakan komponen yang sangat penting untuk diperhatikan guna pencapaian tujuan dari rantai pasokan.Distribusi informasi yang baik di antara pelaku rantai pasokan dapat menciptakan hubungan yang baik dan transparan sehingga mampu meningkatkan kepercayaan serta komitmen dalam menjalankan hubungan kerjasama. Aliran informasi antara pelaku harus dikelola dengan baik secara bersama untuk menghindari asymetric information yang akan menghambat efektifitas serta berpotensi menimbulkan kecurangan dalam suatu kemitraan.Aliran informasi yang terjadi antara anggota rantai pasok adalah kualitas mangga yang diminati konsumen, pasar akhir, jumlah permintaan, teknis budidaya, pasca panen dan harga jual mangga.Informasi soal harga terjadi antar pelaku yang terlibat didalam aliran finansial, informasi tersebut mengalir dari pedagang pengecer di pasar induk, pengepul, pengumpul dan ke petani.

Dari 30 responden petani yang diteliti sebanyak 25 petani mangga atau 83,33 persen tidak mendapatkan informasi mengenai teknis budidaya dan penanganan pasca panen dari anggota rantai pasok berikutnya (pedagang pengumpul dan pedagang pengepul). 5 petani mangga atau 16,67 persen mendapat aliran informasi dari anggota rantai pasok lainnya karena tergabung dengan kelompok tani melati 2. Salah satu alasan yang disampaikan oleh pedagang mengenai tidak disampaikannya informasi pasar dan harga jual mangga kepada petani karena pedagang khawatir petani akan menjual sendiri mangganya ke konsumen akhir. Hal tersebut bebeda dengan aliran informasi yang diterima oleh pedagang pengumpul dari pedagang pengepul. Dari 20 responden pedagang pengumpul 100 persen atau keseluruhan pedagang pengumpul mendapat informasi dari pedagang pengepul mengenai kriteria mangga manalagi berkualitas yang diminati oleh konsumen, pasar mangga, kebutuhan pasar dan harga jual mangga di pasar.

\section{KESIMPULAN}

Kondisi manajemen rantai pasok mangga manalagi di Kabupaten Situbondo saat ini masih belumberjalan dengan baik. Hal tersebut dapat terlihat pada struktur rantai pasok belum yang terintegrasi dengan baik antara anggota primer dalam rantai pasok. Hal tersebut dikarenakan aliran informasi hanya terjadi pada konsumen akhir, pedagang pengecer, pedagang pengepul dan pedagang pengumpul. Sementara petani tidak mendapatkan aliran informasi baik 
mengenai pasar, harga, kualitas dan kuantitas yang diinginkan konsumen kecuali petani yang tergabung dalam kelompok tani. Selain itu, penerapan manajemen danjaringan dalam rantai pasok belum berjalan dengan baik, salah satunya dapat dilihat kesepakatan kontraktual antar anggota rantai pasok tanpa perjanjian tertulis. Sedangkan, pada sumberdaya rantai pasok ditemukan fakta bahwa modal masihmenjadi kendala bagi petani dan pedagang pengumpul. Proses bisnis rantai pasok terkendala karena pada aliran produk mangga dari petani hingga pedagang pengepul belum terintegrasi dengan baik, belum ada siklus yang pasti sehingga waktu pengiriman ataupun kuota yang dikirim tidak bisa diprediksi dengan baik.

\section{DAFTAR PUSTAKA}

Badan Pusat Statistik. 2014. Potret Usaha Pertanian Kabupaten Situbondo Menurut Subsektor. Badan Pusat Statistik Kab. Situbondo.

Lambert DM, Cooper MC, Pagh JD. 1998. Supply Chain Management : Implementation Issues and Research Oppurtunities. The International Journal of Logistics Management. Vol 9(2): 1-19 (25 Mei 2016).

Nugraha AC. 2011. Akar Wangi Di Kabupaten Garut, Jawa Barat. Departemen Manajemen.

Qhoirunisa A. 2014. Rantai Pasok Padi di Kabupaten Bogor Jawa Barat. [tesis]. Bogor (ID) : Institut Pertanian Bogor.

Supriatna A. 2010. Kajian Kelayakan Usahatani Dan Marjin Tataniaga Mangga (Mangifera indica) (Studi kasus di Kabupaten Majalengka , Jawa Barat ), 166178.

Van der Vorst JGAJ. 2006. Quantifying the Agri-Food Supply Chain. Amsterdam (NLD): Logistics and Operations Research Group, Wageningen University. 